\title{
Scientific Ecotourism in Brazil
}

\section{Ecoturismo Científico no Brasil}

\author{
Naiara Stupp Andersen, Bruna Elisa Trentin, Ciro Duarte de Paula Costa, \\ Fernando Campanhã Bechara
}

\begin{abstract}
:
Scientific Ecotourism is an innovative sector of tourism characterized by the development of studies and scientific research in natural areas. We carried out a bibliometric research, searching for scientific publications related to Scientific Ecotourism, being able to characterize the current situation of this segment in Brazil. We searched for papers in Brazilian Ecotourism journals and Google Scholar ${ }^{\mathrm{TM}}$. The parameters used for analysis were: 1) Occurrence of the selected keywords; 2) Type of scientific publication; 3) Year of publication; and 4) Natural protected area category. We found 60 papers, where 17 were discarded because they did not fit specifically the proposed theme. Considering the 43 selected papers, only five clearly mentioned "Scientific Ecotourism", 19 only cited "Scientific Tourism", and another 19 addressed the importance of scientific research in natural areas where Ecotourism already occurs or there is a potential for it to occur. The selected papers comprised the years between 1998 and 2017, and $67 \%$ of these, were performed on Conservation Units (CUs), showing that Scientific Ecotourism is an important management tool for these areas, since it assists the nature conservation and education, and stimulates the economy, both into the $\mathrm{CU}$ as well in the region which it is inserted.
\end{abstract}

KEYWORDS: Protected Natural Areas; Research; Tourism.

RESUMO: Ecoturismo Científico é um inovador ramo do turismo baseado em estudos e pesquisas científicas em áreas naturais. $O$ presente trabalho teve como objetivo realizar uma pesquisa bibliográfica, buscando publicações científicas relacionadas ao Ecoturismo Científico no Brasil, podendo assim caracterizar a atual situação deste segmento no universo acadêmico brasileiro. A pesquisa foi realizada em revistas nacionais de Ecoturismo e no Google Acadêmico ${ }^{\circledR}$. Os parâmetros utilizados para análise das publicações foram: 1) Ocorrência das palavras-chave selecionadas; 2) Tipo de publicação científica; 3) Ano de publicação; e 4) Categoria de área natural protegida. Das 60 publicações encontradas, 17 foram descartadas por não se enquadrarem especificamente no tema proposto. Dos 43 trabalhos selecionados, apenas cinco citaram claramente o "Ecoturismo Científico", 19 mencionaram o "Turismo Científico" e outros 19 trataram da importância da pesquisa científica em áreas naturais onde já ocorre ou existe potencial para o Ecoturismo. Os trabalhos selecionados compreenderam os anos entre 1998 e 2017, sendo que $67 \%$ destes tiveram como local de estudo as Unidades de Conservação (UCs), mostrando que o Ecoturismo Científico é uma importante ferramenta na gestão destas áreas, pois auxilia na educação e conservação da natureza, e fomenta a economia, tanto dentro da UC quanto na região em que ela está inserida.

PALAVRAS CHAVE: Áreas Naturais Protegidas; Pesquisa; Turismo. 


\section{Introduction}

Tourism is defined, by the World Tourism Organization and the Brazilian Ministry of Tourism, as the voluntary and temporary movement of people outside their permanent place of residence for a period of less than a year, except for paid activities (regular jobs) at the place of visit (BRASIL, 2006). Mathieson and Wall (1982) have further refined the concept, including activities developed during the stay in these destinations and the facilities around created to satisfy its needs. This economic sector has emerged over the years in the world showing high growth rates in Brazil, due to its great natural potential associated with the high diversity of ecosystems within different biomes, recognized by its biological value and scenic beauty (BRASIL, 2010).

According to Wearing and Neil (2001), tourism is basically divided into: 1) Mass Tourism and 2) Alternative Tourism. One of the Alternative Tourism segments is the Ecotourism: defined as the contact of tourists with natural environments associate with activities that provide experience and knowledge about nature, as well the inherent protection while using those areas (BRASIL, 2006). We should remember that Ecotourism must not be confused with Sustainable Tourism which, unlike the former, is not seen as a segment of tourism, but as a form of tourism that applies to any segment, considering the economic, social and environmental, present and future, as well as the tourists, industries, environment and local community's needs (UNWTO; UNEP, 2005).

The tourism segments are not necessarily independent. Ecotourism is usually linked to other segments, such as: A) Adventure Tourism, aimed as the practice of non-competitive adventure activities, more or less extremes (BRASIL, 2006); B) Educational or Pedagogical Tourism, which is related to extra-class activities outside the school environment, as field trips, excursions, etc. (MATOS, 2012), usually at high school level and proposing superficial interpretation; and C) Scientific Tourism, pursuing academic and professional knowledge (MAIA, 2015), usually at a higher education level (undergraduate or graduate) and proposing advanced interpretation. However, all of them must meet the basic characteristics of Ecotourism: interpretation, nature conservation and sustainability (BRASIL, 2010).

Scientific Tourism is a segment that has strong interaction with Ecotourism, since many areas of knowledge have an interest in scientific research on natural ecosystems. From this link emerges the "Scientific Ecotourism", based on advanced studies and scientific researches (PIRES, 1998). This tourism segment allows the visitor, in addition to just observe nature, to experience high-level scientific research, including learning methodological techniques with the own researchers, as well as contributing to the conservation of natural resources (NASSAR et al., 2013). It is strongly recommended that the researcher himself works as the guide. As an example, we highlight that just using scientific names in ecological interpretation signs is not a process that configures an approach at a Scientific Ecotourism level (it should be much deeper to characterize it).

In Brazil, Scientific Ecotourism is a term hardly found in scientific papers and still very little discussed. Even if it is a contemporary theme it appears like a knowledge gap in the Tourism field. We aimed to help characterize the current state of the art of this segment in Brazil. 


\section{Material and Methods}

We developed a bibliographic analysis intending to search for scientific information that discusses Ecotourism in Brazil, allowing us to characterize the current scenario of ecotourism in this country. We selected scientific papers searching for publications in Brazilian Ecotourism journals and Google Scholar ${ }^{\mathrm{TM}}$, using the following keywords: Scientific Ecotourism; Scientific Tourism; Ecotourism and Research; Tourism and Research. We found papers from 1998 to 2017. Papers were analyzed following the parameters: 1) Occurrence of the keyword; 2) Type of scientific publication; 3) Year of publication; and 4) Natural protected area category.

\section{Results and Discussion}

We found 60 papers using the selected keywords, where 17 were discarded because they did not specifically address the proposed theme of Scientific Ecotourism. Among the 43 selected publications (Table 1), just 19 registered the term "Scientific Tourism", and the majority of them was related to Ecotourism only because they occurred in natural areas. The remaining 19 articles did not mentioned the Scientific Tourism directly, they only discussed the importance of scientific research in natural areas where Ecotourism already exists or is desired.

Table 1: Selected publications.

Tabela 1: Publicações selecionadas.

\begin{tabular}{|c|c|c|c|}
\hline Authors & Year & Translated Title & Publication/Journal \\
\hline Pires, PS & 1998 & $\begin{array}{l}\text { The conceptual dimension of } \\
\text { ecotourism }\end{array}$ & $\begin{array}{l}\text { Tourism-Vision and } \\
\text { Action }\end{array}$ \\
\hline Barros, PM & 1999 & $\begin{array}{l}\text { Planning model for implementation } \\
\text { and development of ecotourism: } \\
\text { ecotourism diagnosis - case study }\end{array}$ & $\begin{array}{l}\text { Master's Dissertation - } \\
\text { UFSC }\end{array}$ \\
\hline Mourão, GM & 2001 & $\begin{array}{l}\text { Ecological corridors and ecotourism } \\
\text { in the Pantanal }\end{array}$ & Media article \\
\hline Andrade, BB & 2002 & $\begin{array}{l}\text { Multi-agency study of tourism } \\
\text { agencies/operators/ecotourism in the } \\
\text { operation of ecotourism activities in } \\
\text { Santa Catarina Island and in the } \\
\text { region of Santo Amaro da Imperatriz: } \\
\text { sustainable activities or not? }\end{array}$ & $\begin{array}{l}\text { Internship Report - } \\
\text { UFSC }\end{array}$ \\
\hline $\begin{array}{l}\text { Menegasse, LN et } \\
\text { al. }\end{array}$ & 2002 & $\begin{array}{l}\text { Water availability in the karst } \\
\text { Province of Arcos-Pains-Doresópolis, } \\
\text { Alto São Francisco, Minas Gerais, } \\
\text { Brazil }\end{array}$ & Groundwater Journal \\
\hline Seabra, GF & 2003 & $\begin{array}{l}\text { Sertanejo tourism as an economic } \\
\text { alternative to the semi-arid }\end{array}$ & $\begin{array}{l}\text { Journal of Tourism and } \\
\text { Cultural Heritage }\end{array}$ \\
\hline $\begin{array}{l}\text { Fournier, J and } \\
\text { Panizza, AC }\end{array}$ & 2003 & $\begin{array}{l}\text { Contributions of the marine protected } \\
\text { areas for the conservation and } \\
\text { management of the marine } \\
\text { environment }\end{array}$ & $\begin{array}{l}\text { Raega - The } \\
\text { Geographic Space } \\
\text { Under Analysis }\end{array}$ \\
\hline $\begin{array}{l}\text { Sabino, J and } \\
\text { Andrade, LP }\end{array}$ & 2003 & $\begin{array}{l}\text { Ichthyofauna use and conservation in } \\
\text { the ecotourism of the Bonito region, } \\
\text { Mato Grosso do Sul: the myth of } \\
\text { ecological sustainability in the Bahia } \\
\text { Bonita River (Bonito Natural } \\
\text { Aquarium) }\end{array}$ & Neotropical Biota \\
\hline
\end{tabular}

Continue... 
... continuation.

\begin{tabular}{|c|c|c|c|}
\hline Authors & Year & Translated Title & Publication/Journal \\
\hline Albuquerque, IC & 2004 & $\begin{array}{l}\text { The meaning of ecotourism in } \\
\text { Urubici-SC }\end{array}$ & $\begin{array}{l}\text { Master's Dissertation - } \\
\text { UFSC }\end{array}$ \\
\hline $\begin{array}{l}\text { Mamede, SB and } \\
\text { Alho CJR }\end{array}$ & 2004 & $\begin{array}{l}\text { Mammal contemplation tourism of } \\
\text { the Pantanal: an alternative for the } \\
\text { fauna sustainable use }\end{array}$ & Symposium \\
\hline Botezelli, L et al. & 2005 & $\begin{array}{l}\text { Relations among studies of forest } \\
\text { dynamics, biodiversity conservation } \\
\text { and ecotourism. }\end{array}$ & $\begin{array}{l}\text { Electronic Scientific } \\
\text { Journal of Forestry }\end{array}$ \\
\hline Merigue, GOL & 2005 & $\begin{array}{l}\text { The development of Local Productive } \\
\text { Arrangements in tourism: the case of } \\
\text { the tourist region of the east coast of } \\
\text { Mato Grosso do Sul }\end{array}$ & $\begin{array}{l}\text { Virtual Journal of } \\
\text { Tourism }\end{array}$ \\
\hline Oliveira, LAK et al. & 2005 & $\begin{array}{l}\text { Mangroves: tourism and } \\
\text { sustainability }\end{array}$ & $\begin{array}{l}\text { Virtual Journal of } \\
\text { Tourism }\end{array}$ \\
\hline $\begin{array}{l}\text { De Oliveira Filho, } \\
\text { RC and Monteiro, } \\
\text { MSL }\end{array}$ & 2007 & $\begin{array}{l}\text { Economic valuation of ecotourism } \\
\text { practices in the semi-arid region: the } \\
\text { case of Serra da Capivara National } \\
\text { Park - Piauí }\end{array}$ & Symposium \\
\hline Andrade, JA & 2008 & $\begin{array}{l}\text { Scientific tourism in the Amazon: a } \\
\text { study of opportunities, needs and } \\
\text { potentialities for the city of Manaus. }\end{array}$ & $\begin{array}{l}\text { Master's Dissertation - } \\
\text { UFAM }\end{array}$ \\
\hline $\begin{array}{l}\text { Rudzewicz, L and } \\
\text { Lanzer, RM }\end{array}$ & 2008 & $\begin{array}{l}\text { Practices of ecotourism in the Private } \\
\text { Natural Heritage Reserves }\end{array}$ & Hospitality Journal \\
\hline $\begin{array}{l}\text { De Oliveira Filho, } \\
\text { RC and Monteiro, } \\
\text { MSL }\end{array}$ & 2009 & $\begin{array}{l}\text { The Ecotourism in National Park } \\
\text { Serra da Capivara: is it a sustainable } \\
\text { practice? }\end{array}$ & Tourism Review Journal \\
\hline Hintze, HC & 2009 & $\begin{array}{l}\text { Ecotourism in the culture of } \\
\text { consumption: possibility of } \\
\text { Environmental Education or } \\
\text { spectacle? }\end{array}$ & $\begin{array}{l}\text { Brazilian Ecotourism } \\
\text { Journal }\end{array}$ \\
\hline Neiman, Z. et al. & 2009 & $\begin{array}{l}\text { Planning and implementation } \\
\text { participatory of program for } \\
\text { interpretation in trails of the "RPPN } \\
\text { Paiol Maria", Ribeira Valley, Brazil }\end{array}$ & $\begin{array}{l}\text { Brazilian Ecotourism } \\
\text { Journal }\end{array}$ \\
\hline Silva, ELS & 2009 & $\begin{array}{l}\text { Public use plan for the Monte } \\
\text { Roraima National Park: proposal for } \\
\text { the development of a productive } \\
\text { chain of ecotourism in the Cotingo } \\
\text { river basin, based on the principles of } \\
\text { ecological economics. }\end{array}$ & $\begin{array}{l}\text { Master's Dissertation - } \\
\text { UFRGS }\end{array}$ \\
\hline $\begin{array}{l}\text { Becheleni, DG and } \\
\text { Medeiros, ML }\end{array}$ & 2010 & $\begin{array}{l}\text { O turismo como ferramenta para a } \\
\text { proteção do patrimônio cultural } \\
\text { arqueológico: um estudo na APA } \\
\text { Carste de Lagoa Santa-MG }\end{array}$ & $\begin{array}{l}\text { Brazilian Society of } \\
\text { Speleology }\end{array}$ \\
\hline Lobo, HAS et al. & 2010 & $\begin{array}{l}\text { Environmental planning integrated } \\
\text { and participatory to determinate the } \\
\text { provisory tourist carrying capacity in } \\
\text { caves }\end{array}$ & $\begin{array}{l}\text { Tourism and Karst } \\
\text { Landscapes }\end{array}$ \\
\hline
\end{tabular}

Continue... 
... continuation.

\begin{tabular}{|c|c|c|c|}
\hline Authors & Year & Translated Title & Publication/Journal \\
\hline Monteiro, EV & 2010 & $\begin{array}{l}\text { Serra Malagueta Natural Park: its } \\
\text { role in the development of } \\
\text { Ecotourism in Cape Verde }\end{array}$ & $\begin{array}{l}\text { Undergraduate work - } \\
\text { Uni-CV }\end{array}$ \\
\hline Moreira, JC & 2010 & $\begin{array}{l}\text { Geotourism: a historical and } \\
\text { conceptual approach }\end{array}$ & $\begin{array}{l}\text { Tourism and Karst } \\
\text { Landscapes }\end{array}$ \\
\hline Resende, CNF & 2010 & $\begin{array}{l}\text { Ecotourism: an approach to the } \\
\text { Brazilian case }\end{array}$ & $\begin{array}{l}\text { Master's Dissertation - } \\
\text { UBI }\end{array}$ \\
\hline Araújo, LRR et al. & 2011 & $\begin{array}{l}\text { Ecotourism as alternative for } \\
\text { sustainable development of the } \\
\text { Environmental Protection Area of } \\
\text { "Morro do Arubu" - Aracaju (SE), } \\
\text { Brazil }\end{array}$ & $\begin{array}{l}\text { Brazilian Ecotourism } \\
\text { Journal }\end{array}$ \\
\hline Bellinassi, S et al. & 2011 & $\begin{array}{l}\text { Management and Public Use of } \\
\text { Protected Areas: an approach to the } \\
\text { challenges and possibilities. }\end{array}$ & $\begin{array}{l}\text { Brazilian Ecotourism } \\
\text { Journal }\end{array}$ \\
\hline Coelho, FJF & 2011 & $\begin{array}{l}\text { Ecotourism in question: the } \\
\text { possibilities of interpretation and } \\
\text { environmental sustainable } \\
\text { development in the Environmental } \\
\text { Protection Area (APA) Lagoa do Iriry, } \\
\text { Rio das Ostras (RJ), Brazil }\end{array}$ & $\begin{array}{l}\text { Brazilian Ecotourism } \\
\text { Journal }\end{array}$ \\
\hline Rodrigues, JCR & 2011 & $\begin{array}{l}\text { Mitigating and compensatory actions } \\
\text { for a sustainable ecotourism in the } \\
\text { city of Jacinto Machado (SC, Brazil) } \\
\text { by identifying the impacts on the } \\
\text { biological environment }\end{array}$ & $\begin{array}{l}\text { Brazilian Ecotourism } \\
\text { Journal }\end{array}$ \\
\hline Santos, AA & 2011 & $\begin{array}{l}\text { Brazilian National Parks: relationship } \\
\text { between management plans and } \\
\text { ecotourism activity. }\end{array}$ & $\begin{array}{l}\text { Brazilian Ecotourism } \\
\text { Journal }\end{array}$ \\
\hline $\begin{array}{l}\text { Schindwein, MN et } \\
\text { al. }\end{array}$ & 2011 & $\begin{array}{l}\text { Activity of observation the behavior of } \\
\text { Sotalia guianensis as support for } \\
\text { Scientific Tourism in the Parque } \\
\text { Estadual da Ilha do Cardoso } \\
\text { (Cananeia, SP, Brazil) }\end{array}$ & $\begin{array}{l}\text { Brazilian Ecotourism } \\
\text { Journal }\end{array}$ \\
\hline $\begin{array}{l}\text { Silva, EG and } \\
\text { Meneses, LF }\end{array}$ & 2011 & $\begin{array}{l}\text { Inventory of geosites as subsidy for the } \\
\text { geotourism of the municipality of } \\
\text { Gurjão (PB, Brazil) }\end{array}$ & $\begin{array}{l}\text { Brazilian Ecotourism } \\
\text { Journal }\end{array}$ \\
\hline $\begin{array}{l}\text { Bulhões, TG et } \\
\text { al. }\end{array}$ & 2013 & $\begin{array}{l}\text { The Ecotourism in Santo Antônio } \\
\text { Itambé (MG, Brazil) as an inducer of } \\
\text { community involvement in the } \\
\text { surroundings of Protect Areas }\end{array}$ & $\begin{array}{l}\text { Brazilian Ecotourism } \\
\text { Journal }\end{array}$ \\
\hline $\begin{array}{l}\text { Dos Santos, MS } \\
\text { and Moreira, JC }\end{array}$ & 2013 & $\begin{array}{l}\text { Itaimbé do Guartelá Ecotourism: } \\
\text { Sustainability and valorization of the } \\
\text { history and culture of the Guartelans. }\end{array}$ & Symposium \\
\hline Nassar, PM et al. & 2013 & $\begin{array}{l}\text { Viability of scientific ecotourism with } \\
\text { jaguar in Mamirauá reserve, Amazonia }\end{array}$ & Uakari Journal \\
\hline Ribeiro, EM & 2013 & $\begin{array}{l}\text { Foresight and Sustainability of } \\
\text { Ecotourism: use of the scenario } \\
\text { building technique in the State of } \\
\text { Amazonas. }\end{array}$ & Doctoral Thesis - UnB \\
\hline $\begin{array}{l}\text { Barros, RP and } \\
\text { Santos, JB }\end{array}$ & 2014 & $\begin{array}{l}\text { The ecotourism in Alagoas (Brazil) as } \\
\text { an instrument for adoption to good } \\
\text { environmental practices }\end{array}$ & $\begin{array}{l}\text { Brazilian Ecotourism } \\
\text { Journal }\end{array}$ \\
\hline
\end{tabular}

Continue... 
continuation.

\begin{tabular}{|c|c|c|c|}
\hline Authors & Year & Translated Title & Publication/Journal \\
\hline Zaú, AS & 2014 & $\begin{array}{l}\text { The conservation of natural areas and } \\
\text { the Ecotourism }\end{array}$ & $\begin{array}{l}\text { Brazilian Ecotourism } \\
\text { Journal }\end{array}$ \\
\hline $\begin{array}{l}\text { Paula, SF and } \\
\text { Castro, PTA }\end{array}$ & 2015 & $\begin{array}{l}\text { Anthropogenic geomorphology } \\
\text { anthropogenic related to gold mining in } \\
\text { the eighteenth century: scientific and } \\
\text { educational bases on the proposition of } \\
\text { a urban geoturistic trail in Ouro Preto } \\
\text { City (MG, Brazil) }\end{array}$ & $\begin{array}{l}\text { Brazilian Ecotourism } \\
\text { Journal }\end{array}$ \\
\hline $\begin{array}{l}\text { Pereira, AIA et } \\
\text { al. }\end{array}$ & 2015 & $\begin{array}{l}\text { Development Influence of the training } \\
\text { courses of Golfinho Rotador Project in } \\
\text { the profess-sional acting of conductors } \\
\text { eco-tourism in Fernando de Noronha } \\
\text { (PE, Brazil): a contribution to tourist } \\
\text { sustainability local }\end{array}$ & $\begin{array}{l}\text { Brazilian Ecotourism } \\
\text { Journal }\end{array}$ \\
\hline Kiyotani, IB et al. & 2016 & $\begin{array}{l}\text { Tourism in Protected Areas: the } \\
\text { Botanical Gardens Benjamin } \\
\text { Maranhao, Joao Pessoa (PB, Brazil) }\end{array}$ & $\begin{array}{l}\text { Brazilian Ecotourism } \\
\text { Journal }\end{array}$ \\
\hline Cruz, SHR et al. & 2017 & $\begin{array}{l}\text { Ecotourism and local development in } \\
\text { National Forest Caxiuanã/Melgaço } \\
\text { (PA, Brazil) }\end{array}$ & $\begin{array}{l}\text { Brazilian Ecotourism } \\
\text { Journal }\end{array}$ \\
\hline Ibiapina, MM & 2017 & $\begin{array}{l}\text { The ecotourism development on the } \\
\text { Barrinha Beach, llha das Canárias } \\
\text { (MA, Brazil) }\end{array}$ & $\begin{array}{l}\text { Brazilian Ecotourism } \\
\text { Journal }\end{array}$ \\
\hline
\end{tabular}

In relation to the selected papers, 32 were scientific articles, six Master's dissertations, two extended abstracts, one media article, one undergraduate work and one internship report. The selected publications date from 1998 to 2017. The years 2010 and 2011 were the most representative in publications on Scientific Tourism and scientific research in natural areas. Figure 1 shows the evolution of publications over the years, where we can observe a decrease of publications in the last six years.

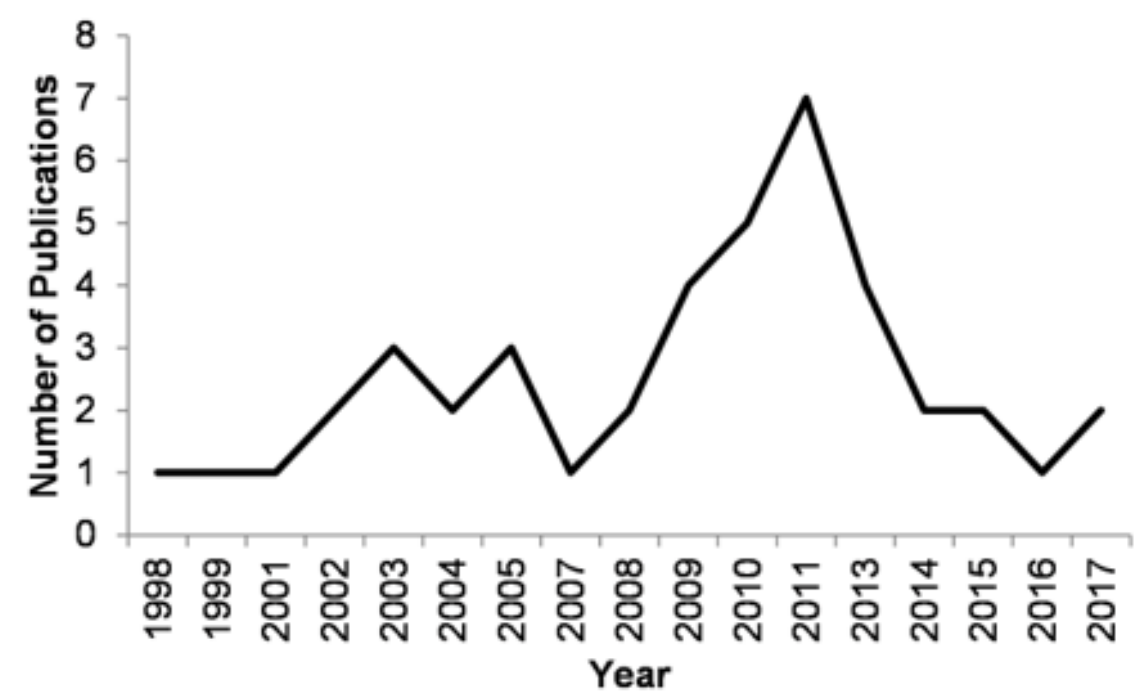

Figure 1: Number of publications per year among the selected papers.

Figura 1: Número de publicações por ano entre os trabalhos selecionados. 
Only five papers mentioned "Scientific Ecotourism" and only three of them presented the definition of the term in the bibliographic review; one mentioned a sightseeing package in the Mamirauá Sustainable Development Reserve (NASSAR et al., 2013), and other described the potential of the Pantanal in Mato Grosso and the coast of Paraíba (RESENDE, 2010). Among these, four were Master's dissertations and one was an internship report. Regarding publication dates, we observed that the theme of Scientific Ecotourism was explicitly mentioned only in the years of 1999, 2002, 2004, 2010 and 2013, showing that it is a recent and poorly widespread science in Brazil.

Considering the papers, 67\% (31) were implemented in Conservation Units (CUs), 20\% (9) in Permanent Preservation Areas or Legal Reserves, and 16\% (6) did not specify a study site. Considering the occurrences in CUs, they usually showed Scientific Tourism and scientific research as important tools for conservation and sustainable use. Among the categories of CUs, the greatest number of studies, that were related to Ecotourism, were carried out in National Parks (29\%), followed by Environmental Protected Areas (23\%) and State Parks (13\%) (Figure 2).

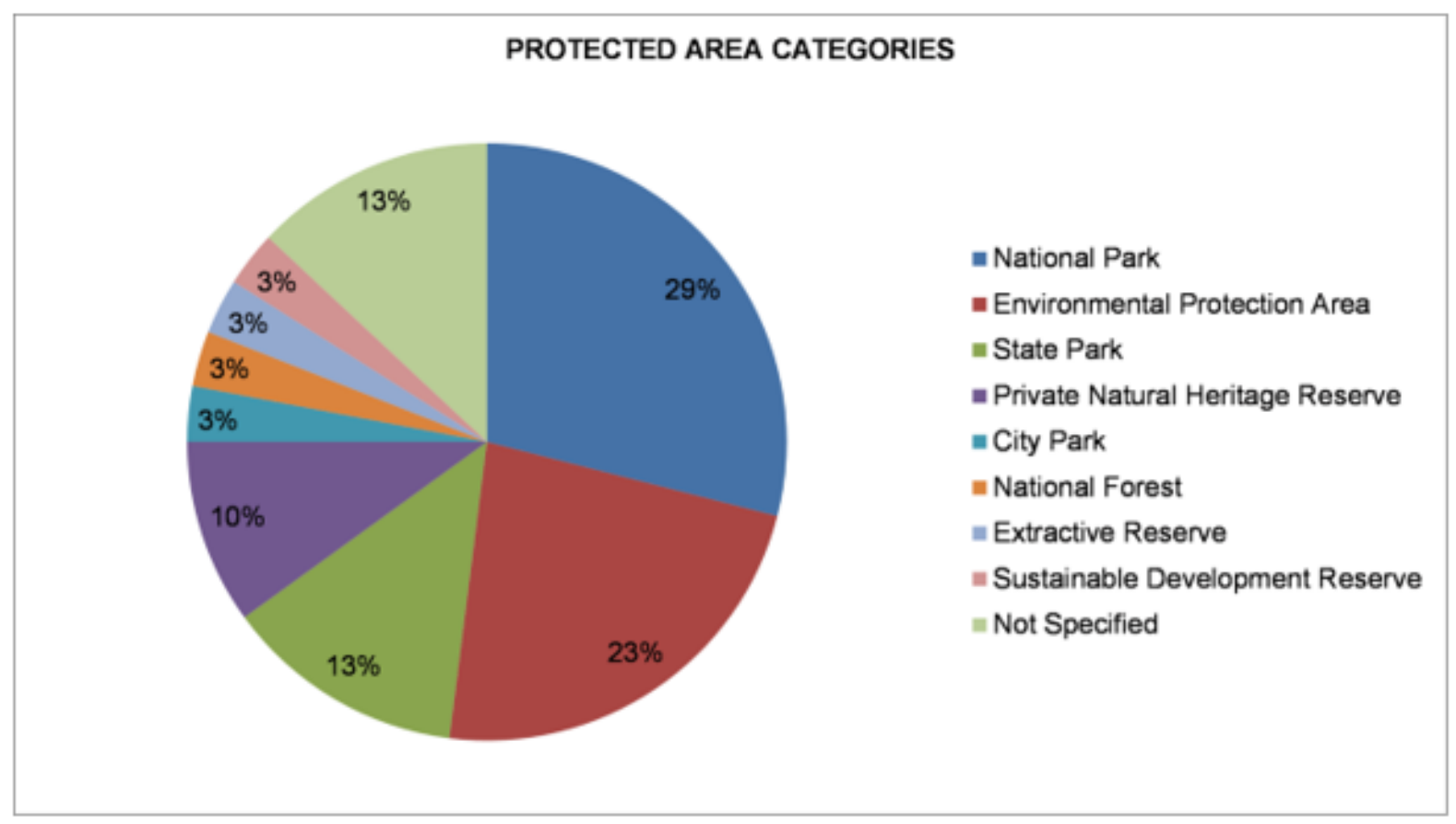

Figure 2: Categories of Conservation Units of the studies developed in natural areas.

Figura 2: Categorias de Unidades de Conservação dos estudos desenvolvidos em áreas naturais.

It was evidenced that ecotourism in protected natural areas, although often associated with research and scientific tourism, does not take advantage of the term "Scientific Ecotourism", which could add more credibility and marketing value to it. There are several ways to promote sustainable development in Conservation Units, and Scientific Ecotourism is a potential tool for it, through the high knowledge of natural resources. Scientific researches implemented in these ecosystems are important, since they provide not just the basis for regional Mass Tourism but also for the managers and environmental education of local communities, while providing scientific contribution to them as well (Figure 3). In order to better understand the 
level of the tourists who seek environmental education, the horizontalization of scientific knowledge, i.e., the "translation" of this knowledge into a more accessible language to the different publics that visit these areas, is necessary. However, for visitors seeking the experience of Scientific Ecotourism, it becomes necessary not only the scientific basis of the information, but also specialized guides and monitors (preferably researchers), avoiding mistaken transmission of this high knowledge. Frequently, it is still necessary to use the English language, universal, in the scientific fields, and adding the opportunity to explore the important and profitable niche of the International Tourism.

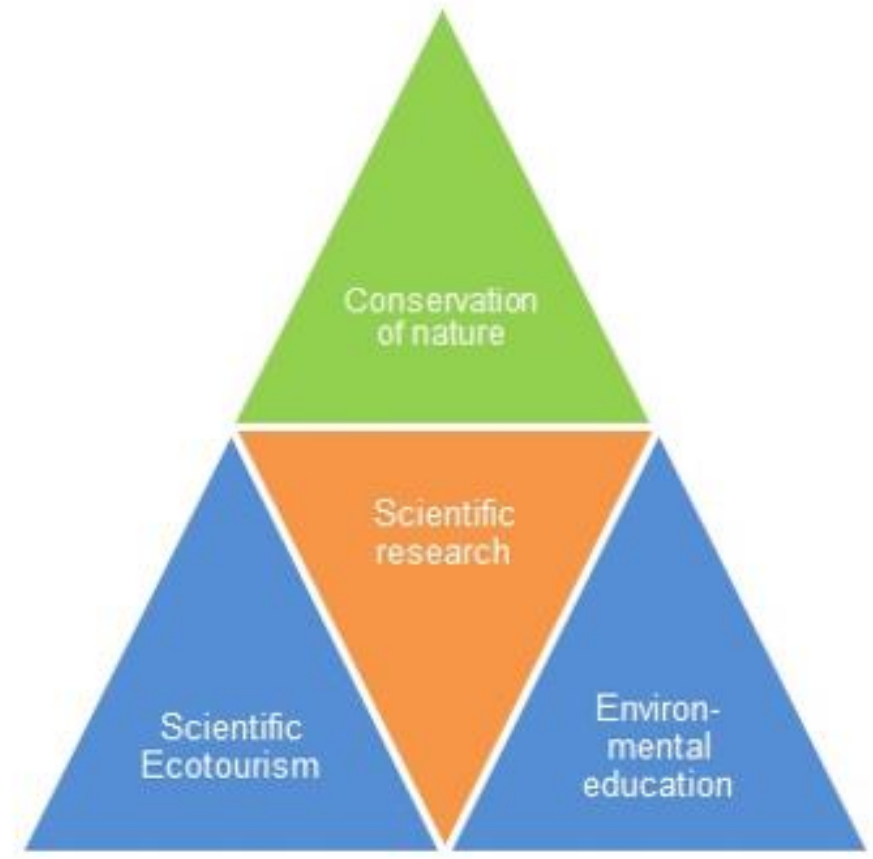

Figure 3: Scientific research as a basis for Nature Conservation, through Scientific Ecotourism and Environmental Education.

Figura 3: Pesquisa científica como base para a Conservação da Natureza, através do Ecoturismo Científico e Educação Ambiental.

Finally, in addition to encourage conservation, tourism development in natural areas may assist the economic sustainability of the CUs, as well as the regional economy, due to the need to adapt the local communities to the increasing demand for specialized tourist gears and services.

\section{References}

ALBUQUERQUE, I.C. et al. O papel do ecoturismo no Município de Urubici - SC. Dissertação (Mestrado em Engenharia Ambiental) - Centro Tecnológico Universidade Federal de Santa Catarina, Florianópolis, 2004.

ANDRADE, B.B. Estudo de multicasos das agências e operadoras de turismo/ecoturismo na operalização das atividades ecoturísticas na llha de santa Catarina e na região de Santo Amaro da Imperatriz: atividades sustentáveis ou não?

- Trabalho de Conclusão de Estágio - Universidade Federal de Santa Catarina, Florianópolis, 2002. 
ANDRADE, J.A. O turismo científico na Amazônia: um estudo das oportunidades, necessidades e potencialidades para a cidade de Manaus. Dissertação (Mestrado em Ciências Florestais e Ambientais). Univ. Federal do Amazonas, Manaus, 2008.

ARAÚJO, L.R.R.; FREITAS, D.M.A.; BRAGHINI, C.R. Ecoturismo como alternativa para o desenvolvimento sustentável da Área de Proteção Ambiental do Morro do Urubu - Aracaju (SE). Revista Brasileira de Ecoturismo, v.4, n.2, p. 228-249, 2011.

BARROS, P.M. Modelo de planejamento para implementação e desenvolvimento do ecoturismo: diagnóstico ecoturístico-estudo de caso. Dissertação (Mestrado em Engenharia de Produção) - Univ. Federal de Santa Catarina, Florianópolis, 1999.

BARROS, R. P.; SANTOS, J. B. O ecoturismo em Alagoas como um instrumento de adoção de boas práticas ambientais. Revista Brasileira de Ecoturismo, v.7, n.2, p.240-250, 2014.

BECHELENI, D.G.; MEDEIROS, M.L. O turismo como ferramenta para a proteção do patrimônio cultural arqueológico: um estudo na APA Carste de Lagoa Santa-MG. Sociedade Brasileira de Espeleologia, p. 21, 2010.

BELLINASSI, S.; PAVÃO, A.C.; CARDOSO-LEITE, E. Gestão e Uso Público de Unidades de Conservação: um olhar sobre os desafios e possibilidades. Revista Brasileira de Ecoturismo, v.4, n.2, p. 274-293, 2011.

BOTEZELLI, L.; MACEDO, R.L.G.; YOSHITANI JUNIOR, M.; GOMES, J.E. Relações entre estudos da dinâmica florestal, conservação da biodiversidade e ecoturismo. Revista Científica Eletrônica de Engenharia Florestal, v. 03, n. 06, p.1-4, 2005.

BRASIL. Ministério do Turismo. Ecoturismo: orientações básicas. Brasília, 2010.

BRASIL. Ministério do Turismo. Segmentação do Turismo: Marcos Conceituais. Brasília, 2006.

BULHÕES, T.G.; BULHÕES, N.G.; GONTIJO, B.M. O Ecoturismo em Santo Antônio do Itambé (MG) como indutor do envolvimento comunitário no entorno de Unidades de Conservação. Revista Brasileira de Ecoturismo, v.6, n.4, p.45-62, 2013.

COELHO, F.J.F. Ecoturismo em questão: possibilidades de interpretação ambiental e desenvolvimento sustentável na Área de Proteção Ambiental da Lagoa de Iriry, Rio das Ostras (RJ). Revista Brasileira de Ecoturismo, v.4, n.1, p.59-68, 2011.

CRUZ, S.H.R; MENDES, F.L.S.; CAMPOS, R.I.R. Ecoturismo e desenvolvimento local na Floresta Nacional de Caxiuanã/Melgaço (PA). Revista Brasileira de Ecoturismo, v.9, n.6, p.737-750, 2017.

FOURNIER, J.; PANIZZA, A.C. Contribuições das áreas marinhas protegidas para a conservação e a gestão do ambiente marinho. Raega - O Espaço Geográfico em Análise, v. 7, 2003.

HINTZE, H.C. Ecoturismo na cultura de consumo: possibilidade de Educação Ambiental ou espetáculo? Revista Brasileira de Ecoturismo, v.2, n.1, p.57-100, 2009.

IBIAPINA, M.M. O desenvolvimento do ecoturismo na Praia da Barrinha na Ilha das Canárias (MA). Revista Brasileira de Ecoturismo, v.9, n.6, p.713-736, 2017.

KIYOTANI, I.B.; SOUSA, F.G.; TAVARES, A.G. Turismo em Unidades de Conservação: o Jardim Botânico Benjamim Maranhão, João Pessoa (PB). Revista Brasileira de Ecoturismo, v.8, n.5, p.684-707, 2016. 
LOBO, H.A.S.; MARINHO, M.A.; TRAJANO, E.; SCALEANTE, J.A.B.; ROCHA, B. A.; SCALEANTE, O.A.F.; LATERZA, F.V. Planejamento ambiental integrado e participativo na determinação da capacidade de carga turística provisória em cavernas. Turismo e Paisagens Cársticas, v. 3, n. 1, 2010.

MAIA, M.J.C.S. Projeto de um Plano de Marketing de Turismo Científico para a Universidade do Porto. Dissertação (Mestrado em Marketing) - Departamento de Economia e Gestão - Universidade do Porto, Porto, 2015.

MERIGUE, G.L. O desenvolvimento de Arranjos Produtivos Locais no turismo: o caso da região turística da costa leste de Mato Grosso do Sul. Caderno Virtual de Turismo, v. 5, n. 1, 2005.

MAMEDE, S.B.; ALHO C.J.R. Turismo de contemplação de mamíferos do Pantanal: alternativa para o uso sustentável da fauna. Anais... IV Simpósio sobre Recursos Naturais e Sócio-econômicos do Pantanal. Anais, Empresa Brasileira de Pesquisa Agropecuária (Embrapa)-Pantanal, Corumbá, 2004.

MATHIESON, A; WALL, G. Tourism: economic, physical and social impacts. London: Longman, 1982. 208p.

MATOS, F.C. Turismo Pedagógico: o estudo do meio como ferramenta fomentadora do currículo escolar. Anais... VII Seminário de Pesquisa em Turismo Do Mercosul. Caxias do Sul, 2012.

MENEGASSE, L.N.; GONÇALVES, J.M.; FANTINEL, L.M. Disponibilidades hídricas na Província cárstica de Arcos-Pains-Doresópolis, Alto São Francisco, Minas Gerais, Brasil. Águas Subterrâneas, v. 16, n. 1, 2002.

MONTEIRO, E.V. Parque Natural de Serra Malagueta: seu papel no desenvolvimento do Ecoturismo em Cabo Verde. Trabalho de Conclusão de Curso - Universidade de Cabo Verde, Praia, 2010.

MOREIRA, J.C. Geoturismo: uma abordagem histórico-conceitual. Turismo e Paisagens Cársticas, v. 3, n. 1, p.5-10, 2010.

MOURÃO, G.M. Corredores ecológicos e ecoturismo no Pantanal. Embrapa Pantanal. Artigo de Divulgação na Mídia, 2001.

NASSAR, P.M.; RAMALHO, E.E.; RONIS, R.S. Economic and market viability of scientific ecotourism related to the jaguar in a várzea area in central Amazonia. Uakari, v. 9, p.21-32, 2013.

NEIMAN, Z.; CARDOSO-LEITE, E.; PODADERA, D.S. Planejamento e implantação participativos de programas de interpretação em trilhas na "RPPN Paiol Maria", Vale do Ribeira (SP). Revista Brasileira de Ecoturismo, v.2, n.1, pp.11-34, 2009.

OLIVEIRA FILHO, R.C.; MONTEIRO, M.S.L. Ecoturismo no Parque Nacional Serra da Capivara: trata-se de uma prática sustentável?. Revista Turismo em Análise, v. 20, n. 2, p.230-250, 2009.

OLIVEIRA FILHO, R.C.; MONTEIRO, M.S.L. Valoração econômica da prática do ecoturismo no semi-árido: o caso do Parque Nacional Serra da Capivara -Piauí. Anais... VII Encontro da Sociedade Brasileira de Economia Ecológica, Fortaleza, 2007.

OLIVEIRA, L.A.K.; FREITAS, R.R.; BARROSO, G.F. Manguezais: turismo e sustentabilidade. Caderno Virtual de Turismo, v. 5, n. 3, 2005. 
PAULA, S.F; CASTRO, P.T.A. Geomorfologia antropogênica em função da mineração de ouro no século XVIII: bases científicas e educativas na proposição de uma Trilha Geoturística Urbana na Sede no Município de Ouro Preto (MG). Revista Brasileira de Ecoturismo, v.8, n.4, p.432-443, 2015.

PEREIRA, A.I.A.; SILVA, F.J.L.; SILVA-JUNIOR, J.M. Influência dos cursos de capacitação do Projeto Golfinho Rotador na atuação profissional dos condutores de ecoturismo em Fernando de Noronha (PE): uma contribuição a sustentabilidade turística local. Revista Brasileira de Ecoturismo, v.8, n.1, p.31-58, 2015.

PIRES, P.S. A dimensão conceitual do ecoturismo. Turismo - Visão e Ação, v.1, p.75-91, 1998.

RESENDE, C.N.F. Ecoturismo: uma abordagem ao caso brasileiro. 2010. Dissertação (Mestrado em Marketing) - Departamento de Gestão e Economia Universidade da Beira Interior, Covilhã, 2010.

RIBEIRO, E.M. Prospectiva e Sustentabilidade do Ecoturismo: uso da técnica de construção de cenários no Estado do Amazonas. Tese (Doutorado) - Universidade de Brasília, Brasília, 2013.

RODRIGUES, J.C.R. Ações mitigadoras e compensatórias para um Ecoturismo sustentável no município de Jacinto Machado (SC), através da identificação dos impactos no meio biológico. Revista Brasileira de Ecoturismo, v.4, n.3, p.383-416, 2011.

RUDZEWICZ, L.; LANZER, R.M. Práticas de ecoturismo nas Reservas de Patrimônio Natural. Revista Hospitalidade, v. 5, n. 1, p. 81-96, 2008.

SABINO, J.; ANDRADE, L.P. Uso e conservação da ictiofauna no ecoturismo da região de Bonito, Mato Grosso do Sul: o mito da sustentabilidade ecológica no Rio Baía Bonita (Aquário Natural de Bonito). Biota Neotropica, v. 3, n. 2, p. 1-9, 2003.

SANTOS, M.S.; MOREIRA, J.C. Itaimbé do guartelá ecoturismo: sustentabilidade e valorização da história e cultura dos guartelanos. Anais... VII Fórum Internacional De Turismo Do Iguassu. Foz do Iguaçu, 2013.

SANTOS. A.A. Parques Nacionais Brasileiros: relação entre Planos de Manejo e a atividade ecoturística. Revista Brasileira de Ecoturismo, v.4, n.1, p.141-162, 2011.

SEABRA, G.F. O turismo sertanejo como alternativa econômica para o semi-árido. PASOS. Revista de Turismo y Patrimonio Cultural, v. 1, n. 2, 2003.

SCHINDWEIN, M.N.; AKAKI, A.T.; LAGANARO, N.M. Atividades de observação do comportamento de Sotalia guianensis como subsídio para o Turismo Científico no Parque Estadual Ilha do Cardoso - Cananeia (SP). Revista Brasileira de Ecoturismo, v.4, n.2, p.196-207, 2011.

SILVA, E.G.; MENESES, L.F. Inventário de geossítios como subsídio para o geoturismo no município de Gurjão (PB). Revista Brasileira de Ecoturismo, v.4, n.3, p.361-382, 2011.

SILVA, E.L.S. Plano de uso público do Parque Nacional do Monte Roraima: proposta de estruração de uma cadeia produtiva de ecoturismo na calha do rio Cotingo, com base nos princípios da economia ecológica. Dissertação (Mestrado) - Universidade Federal do Rio Grande do Sul, Porto Alegre, 2009. 
PIRES, P.A.S. dimensão conceitual do ecoturismo. Turismo-Visão e Ação, v. 1, n. 1, p. 75, 1998.

UNWTO; UNEP. Making Tourism More Sustainable - A Guide for Policy Makers. New York: UNEP UNWTO, 2005.

WEARING, S. NEIL, J. Expanding sustainable tourism's conceptualization: ecotourism, volunteerism and serious leisure. In: MCCOOL, S.F.; MOISEY, R.N. (eds). Tourism, recreation and sustainability: Linking culture and the environment. Wallingford: CABI Publishing, p. 233-254, 2001.

ZAÚ, A.S. A conservação de áreas naturais e o Ecoturismo. Revista Brasileira de Ecoturismo, v.7, n.2, p.290-321, 2014.

Naiara Stupp Andersen: Universidade Tecnológica Federal do Paraná, Dois Vizinhos, PR, Brasil

E-mail: naiara_andersen@outlook.com

Link para o currículo Lattes: http://lattes.cnpq.br/6052956076078670

Bruna Elisa Trentin: Universidade Tecnológica Federal do Paraná, Dois Vizinhos, PR, Brasil

E-mail: brunaelisatrentin@gmail.com

Link para o currículo Lattes: http://lattes.cnpq.br/3751751701407251

Ciro Duarte de Paula Costa: Neofloresta Serviços Ecossistêmicos, Pato Branco, PR, Brasil

E-mail: ciro.floresta@gmail.com

Link para o currículo Lattes: http://lattes.cnpq.br/2212910454235279

Fernando Campanhã Bechara: Universidade Tecnológica Federal do Paraná, Dois Vizinhos, PR, Brasil

E-mail: bechara.utfpr@gmail.com

Link para o currículo Lattes: http://lattes.cnpq.br/8651851040427432

Data de submissão: 28 de fevereiro de 2019

Data de recebimento de correções: 14 de abril de 2019

Data do aceite: 14 de abril de 2019

Avaliado anonimamente 